\title{
EGFR NM_005228.3:C.2386G>A
}

National Cancer Institute

\section{Source}

National Cancer Institute. EGFR NM 005228.3:c.2386G>A. NCI Thesaurus. Code

C147022.

A nucleotide substitution at position 2386 of the coding sequence of the EGFR gene where guanine has been mutated to adenine. 